\title{
Integrated multivariate analysis to identify superior cowpea genotypes
}

\author{
Adriano dos Santos'*, Gessí Ceccon², Livia Maria Chamma Davide³, \\ Antonio Luiz Neto $\mathrm{Neto}^{3}$, Juslei Figueiredo da Silva ${ }^{3}$, Rita de Cássia Félix Alvarez ${ }^{4}$ \\ 'North Fluminense State University Darcy Ribeiro, Campos dos Goytacazes, RJ, Brazil \\ 2Brazilian Agricultural Research Corporation - Agropecuária Oeste, Dourados, MS, Brazil \\ ${ }^{3}$ Federal University of Grande Dourados, Dourados, MS, Brazil \\ ${ }^{4}$ Federal University ofMato Grosso Do Sul, Chapadão do Sul, MS, Brazil \\ Corresponding author, e-mail: adriano.agro84@yahoo.com.br
}

\begin{abstract}
Genetic divergence among 40 cowpea genotypes was quantified by means of integrated multivariate analysis aiming to assist the selection and development of new cultivars. The experiment was carried out in randomized blocks design with 40 treatments and 4 repetitions. The multivariate techniques applied were partially concordant, following the same trend for clustering of genotypes. Directed crosses between the genotypes belonging to group I with group IV and VI will be able to lead to the creation of segregating families with high yield potential and an increase in probability of recovering individuals. The variables of hundred grain weight, average pod length and number of seeds per pod are the main determinants in quantification of the genetic divergence among cultivars.
\end{abstract}

Keywords: Dissimilarity, selection, Vigna unguiculata

\section{Análise multivariada integrada na identificação de genótipos superiores de feijão-caupi}

\section{Resumo}

A divergência genética entre 40 genótipos de feijão-caupi, foi quantificada por meio da análise multivariada integrada, com a finalidade de auxiliar na seleção e no desenvolvimento de novos cultivares. O delineamento experimental foi em blocos casualizados, com 40 tratamentos e 4 repetições. As técnicas multivariadas aplicadas foram parcialmente concordantes entre si, seguindo a mesma tendência de agrupamento dos genótipos. O cruzamento dirigido entre os genótipos pertencentes ao grupo I com o grupo IV e VI poderá propiciar a criação de famílias segregantes com elevado potencial produtivo e aumento na probabilidade de recuperar indivíduos. As variáveis, massa de cem grãos, comprimento médio da vagem e número de grãos por vagem são os principais determinantes na quantificação da divergência genética entre as cultivares.

Palavras-chave: Dissimilaridade, seleção, Vigna unguiculata 


\section{Introduction}

Breeding of cowpea is mainly based on parents selection, followed by hybridization, in order to form a base population base and generation advance, with simultaneous selection for more than one trait (Bertini et al., 2010). In identification of parents for hybridization, the selection of genotypes within the most divergent groups is recommended, with greater mean values for the characteristics that are the target of the breeding process (Passos et al., 2007).

Analysis of genetic divergence seeks to identify parents for creating populations with genetic variability and consequent genetic gain in successive selection cycles. Some methodologies have been used in the characterization of germplasm, such as the use of isoenzymes and molecular markers (Pinto et al. 2004 and Dutra Filho et al., 2013). Another choice that may be made is the multivariate analysis of morphological and agronomic data, which is a lower cost option, only requiring field evaluations and knowledge of statistical methods.

Multivariate statistics is a set of statistical methods used in situations in which different variables, continuous or not, are measured simultaneously in each experimental unit (Santos et al., 2010). Multivariate data analysis methods allow an overall study of these variables, placing the connections, similarities or differences among them in evidence, with minimal information losses. In forecasting genetic divergence, different multivariate methods may be applied. Among these methods, the most used are: principal component analysis, canonical variate analysis and the cluster analysis methods (Oliveira et al., 2003).

The most used cluster analysis methods in genetic breeding are the hierarchical cluster analysis and the cluster analysis optimization. In the hierarchical methods, the accessions are clustered by a process that is repeated in various levels until a dendrogram or graph is established, with no concern about the optimum number of groups, but rather with the topology of the dendrogram visually examined (Cruz et al., 2006 and Ferreira et al., 2007). For the optimization methods, location of accessions in subclusters is performed with a view toward the maximization or minimization of some pre-established measure. One of the most commonly used optimization methods in genetic breeding is Tocher's method.

The canonic variate analysis is an alternative when experimental data with replications is available and the weighting coefficient of the original variables may be estimated in each one of the canonical variates and their variances. Principal component analysis may be performed even when the researcher does not have experimental data with replications available, and this method evaluates if there is a small number of the first principal components which are responsible for explaining a high proportion of the total variation associated with the original set. Thus, it promotes elimination of traits that contribute little to the variation of the individuals evaluated and allows the clustering of similar individuals by means of graph dispersions (Gonçalves \& Fritsche-Neto, 2012).

The choice of the most adequate method has been determined by the precision desired by the researcher, by the ease of analysis and by the manner that the data were obtained (Bezerra Neto et al., 2010). Multivariate analysis may furthermore be applied in an integrated manner, where a set of multivariate techniques is used simultaneously in such a way as to provide for better interpretation of the results.

Therefore, the goal of this study was to quantify the genetic divergence of 40 cowpea genotypes by means of Integrated Multivariate Analysis for the purpose of assisting the parents choice and for new cultivars development..

\section{Materials and Methods}

The experiment was performed with 40 cowpea genotypes, 24 advanced lines and 16 commercial varieties originating from the germplasm bank of Embrapa Meio Norte. The genotypes from 1 to 20 are of upright and semiupright growth habit and from 21 to 40 of prostate and semi-prostate growth habit (Table 1). The studies were conducted in two municipalities of Mato Grosso do Sul State (Dourados and Chapadão do Sul), Brazil, during the fall-winter period of 2009 . 
Table 1. Description of the genotypes used in the experiment.

\begin{tabular}{|c|c|c|}
\hline I.G & Genotypes & Parents/origin \\
\hline 1 & MNC99-537F-1 & TE96-282-22G $\times$ IT87D-611-3 \\
\hline 2 & BRS Tumucumaque & TE96-282-22G x IT87D-61 1-3 \\
\hline 3 & MNC99-541F-5 & TE93-210-13F x TE96-282-22G \\
\hline 4 & MNC99-541F-8 & TE93-210-13F x TE96-282-22G \\
\hline 5 & BRS Potengi & TE96-282-22G x TE93-210-13F \\
\hline 6 & BRS Novaera & TE97-404-1F x TE97-404-3F \\
\hline 7 & MNC00-553D-8-1-2-3 & TE97-404-1F X TE97-404-3F \\
\hline 8 & MNC99-557F-2 & (TE96-282-22G x IT87D-611-3) x TE97-41 1-1F \\
\hline 9 & MNC01-627F-14-2 & TE99-496-1F x TE97-41 1-15F-2-1 \\
\hline 10 & MNC01-627F-14-5 & TE99-496-1F x TE97-41 1-15F-2-1 \\
\hline 11 & MNC03-720C-20 & MNC01-625D-10-2 x TE99-499-1F-2-1 \\
\hline 12 & MNC03-720C-31 & MNC01-625D-10-2 x TE99-499-1F-2-1 \\
\hline 13 & MNC03-731C-21 & TE99-499-1F-2-3 x MNC01-627D-5-1 \\
\hline 14 & MNC03-732C-5 & MNC01-627D-5-1 x TE99-499-1F-2-3 \\
\hline 15 & TVx-5058-09C & IITA, Nigéria \\
\hline 16 & MNC05-784b-38-2 & TE99-499-1F-2-3 x MNC99-544D-10-1-2-2 \\
\hline 17 & MNC05-832b-234-5 & [(MNC00-553D-8-1-2-3 x MNC99-544D-10-1-2-2)] x Urubuquara -1 13 \\
\hline 18 & Vaina Blanca & Iguitos, Peru \\
\hline 19 & californiablackeye-27 & Univ. da California, Riverside \\
\hline 20 & BRS Guariba & IT85-2687 x TE87-98-8G \\
\hline 21 & MNC99-510F-16-1 & Paulista x TE90-180-88F \\
\hline 22 & MNC99-510F-16-3 & Paulista x TE90-180-88F \\
\hline 23 & MNC99-537F-14-2 & TE96-282-22G $\times$ IT87D-611-3 \\
\hline 24 & MNC01-611F-11 & TE97-340-4E $\times$ TE93-222-1 1F \\
\hline 25 & MNC01-614F-15 & TE97-404-1 F-15 x TE93-242-10E-6-1-1 \\
\hline 26 & MNC01-631F-11 & CNCx 409-1 1F-P2-195 x TE97-341-1E-1-1 \\
\hline 27 & MNC01-631F-15 & CNCX 409-1 1F-P2-195 x TE97-341-1E-1-1 \\
\hline 28 & MNC01-631F-20-5 & CNCx 409-1 1 F-P2-195 x TE97-341-1E-1-1 \\
\hline 29 & MNC01-649E-2 & TE97-309G-24 x MNC-01-608D-2-5 \\
\hline 30 & Canapuzinho & São Raimundo Nonato, PI \\
\hline 31 & Canapuzinho-2 & São Raimundo Nonato, PI \\
\hline 32 & Inhuma & Inhuma, PI \\
\hline 33 & Pingo-de-ouro-1-2 & Iguatu, $\mathrm{CE}$ \\
\hline 34 & Pingo-de-ouro-2 & Iguatu, CE \\
\hline 35 & paulistinha & Juazeiro, CE \\
\hline 36 & Patativa & CNC1735 x (CNCx 926-5F x Paulista) \\
\hline 37 & BRS Paraguassu & BR10-Piauí x Aparecido Moita \\
\hline 38 & BRS Milênio & Tracuateua, PA \\
\hline 39 & BR 17-Gurguéia & BR 10-Piauí x CE-315 \\
\hline 40 & BRS Marataoã & Seridó x TVx1836-013J \\
\hline
\end{tabular}

The experimental design was randomized blocks with 40 treatments and 4 replications. The experimental unit consisted of four 5-meter rows spaced at 0.50 meters, considering the two center rows as the useful area.

Harvesting of the plots was performed manually, and in each plot the plants were evaluated for the following traits: green pod length (GPL), average length in $\mathrm{cm}$ of the pods of five plants harvested at random at physiological maturity; pod weight (PW), considering the average weight of the previously harvested pods; number of seeds per pod (NSP), obtained through counting of the seeds in the pods harvested for the previous sampling; seed index (SI) refers to the green seed weight in green pods at physiological maturity; average number of pods per plant (NPP), considering the average of the pods harvested from five plants; hundred grain weight (HSW), weight of 100 seeds with $13 \%$ of moisture; and grain yield (YLD) estimated through the useful area harvested in each plot, converting the results to $\mathrm{kg} \mathrm{ha}^{-1}$ and adjusting the data to $13 \%$ of moisture.

Initially, analysis of variance was performed for each environment in an isolated 
manner, checking the uniformity of residual variance. Afterwards, the variance analysis was performed, considering the two environments.

Analysis of genetic divergence was performed using multivariate techniques. In application of the genotype cluster analysis technique, the Mahalanobis generalized distance $\left(D^{2}\right)$ was adopted as a measure of dissimilarity, taking into consideration the degree of dependence among the studied variables .

In relation to the establishment of similar groups, the agglomerative hierarchical clustering method of optimization proposed by Tocher was applied, whose calculations were equally based on Mahalanobis generalized distance $\left(D^{2}\right)$. Principal component analysis was used, evaluating the relative contribution of each trait to the genetic divergence among them and graph dispersion was developed as a function of the first three principal components. All statistical analyses was carried out using the GENES software (Cruz, 2013).

\section{Results and Discussion}

It may be observed that the mean squares presented a significant difference for all studied characteristics in the GxE interaction by the $\mathrm{F}$ test (Table 2). This result indicates the existence of phenotypic variability, i.e., the genotypes behave in a differentiated manner in the environments, which benefits their characterization process. The significance of the interaction of all the agronomic traits suggests its contribution for identification of the genetic divergence among them.

Table 2. Summary of joint analysis of variance for the seven traits evaluated on 40 cowpea genotypes.

\begin{tabular}{lccccc}
\hline S.V & D.F & GPL & PW & NSP & SI \\
\hline Genotypes (G) & 39 & $39.2400^{* *}$ & $21.4631^{*}$ & $16.4242^{*}$ & $48,3620^{*}$ \\
Environment (E) & 1 & $174.8671^{* *}$ & $1536.6228^{* *}$ & $1.6531^{\text {ns }}$ & $330,9954^{* *}$ \\
G. x E. & 39 & $2.9943^{*}$ & $17.5782^{* *}$ & $8.7364^{* *}$ & $30,6857^{* *}$ \\
Residue & 240 & 1.9231 & 2.6744 & 0.8760 & 7,2837 \\
Mean & & 18.26 & 14.32 & 8.89 & 74,0 \\
CV (\%) & - & 7.59 & 11.41 & 10.52 & 5,61 \\
\hline S.V & & NPP & HSW & \multicolumn{2}{c}{ YLD } \\
\hline Genotypes (G) & 39 & $24.3714^{* *}$ & $46.9176^{* *}$ & $90562.5278^{* *}$ \\
Environment (E) & 1 & $5.7432^{*}$ & $55.1556^{* *}$ & $10026122.5377^{* *}$ \\
G. x E. & 39 & $29.1317^{* *}$ & $32.5606^{* *}$ & $60218.8948^{* *}$ \\
Residue & 240 & 2.6480 & 1.1332 & 8972.1239 \\
Mean & & 9.07 & 18.76 & \multicolumn{2}{c}{642.81} \\
CV (\%) & & 17.92 & 5.67 & \multicolumn{2}{c}{14.73} \\
S.V: source of variation; D.F: degree of freedom: GPL: pod length (cm); PW: pod weight (grams); NSP: number of seeds per pod: Sl: seed index; NPP: number \\
of pods per plant; HSW: hundred grain weight (grams); YLD: grain yield (kg ha').
\end{tabular}

The coefficients of heritability based on the mean of families $\left(h_{\overline{\mathrm{x}}}^{2}\right)$ showed magnitudes from moderate to high for the characteristics of pod length (GPL), pod weight (PW), number of seeds per pod (NSP), seed index (IS), number of pods per plant (NPP), hundred grain weight (HSW) and grain yield (YLD), confirming that most of the phenotype is attributed to genetic causes (Table 3). The low value of heritability observed for grain yield can be explained by the polygenic origin of the character, coming from the sum of the environmental effect of each gene.

The traits that most contributed to genetic diversity were hundred grain weight (HSW) (36.96\%) pod length (GPL) (16.29\%) and the number of seeds per pod (NSP) (15.54\%), indicating the existence of greater genetic variability among these traits in the germplasm studied. What can be seen also by higher heritability values and relation $\mathrm{CV}_{g} / \mathrm{CV}_{\mathrm{e}}$ obtained by these characters. In common bean genotypes, the hundred grain weight, which is a high heritability trait, is the variable which most contributes to genetic divergence (Elias et al., 2007 and Cabral et al., 2011).

In regard to cowpea, studies on genetic divergence have shown discordant results in relation to the contribution of each component to the diversity. In their study, Nagalakshmi et al. (2010) describe that grain yield and hundred 
grain weight were the traits that most contributed to divergence. Nevertheless, it should be highlighted that seed production is a complex trait, generally of quantitative inheritance and with high environment influence, which may be the reason for this greater contribution.

Table 3. Genetic parameters and relative contribution of each trait to genetic dissimilarity (S.j') in 40 cowpea genotypes.

\begin{tabular}{ccccccc}
\hline Variable & $h_{\bar{x}}^{2}$ & $C V_{g}$ & $C V_{g} / C V_{e}$ & S.j' & $\%$ & accumulated \% \\
\hline GPL & 95.18 & 11.82 & 1.57 & 3472.1196 & 16.2929 & 16.293 \\
PW & 87.97 & 10.72 & 0.95 & 1026.8763 & 4.8186 & 21.112 \\
NSP & 94.55 & 15.67 & 1.47 & 3312.4336 & 15.5436 & 36.655 \\
SI & 64.10 & 2.66 & 0.47 & 643.0035 & 3.0173 & 39.672 \\
NPP & 63.40 & 18.56 & 1.31 & 2895.2734 & 13.586 & 53.258 \\
HSW & 83.78 & 12.75 & 2.27 & 7875.6307 & 36.9563 & 90.215 \\
YLD & 61.38 & 9.58 & 0.65 & 2085.3185 & 9.7853 & 100.000 \\
\hline GPL: pod length (cm); PW: pod weight (grams); NSP: number of seeds per pod; Sl: seed index; NPP: number of pods per plant; HSW: hundred grain weight (grams); YLD: grain
\end{tabular}
yield $\left(\mathrm{kg} \mathrm{ha}^{-1}\right)$.

Dias et al. (2009) verified that the variables that most contributed to divergence in cowpea were the maturity cycle, number of nodes on the main stem and the beginning of flowering.

It may furthermore be observed, regarding the relative contribution of each trait that grain yield had low discriminating power among the accessions, even showing productive heterogeneity among the genotypes (Table 3).

The maximum value of genetic divergence $\left(D^{2}=219.49\right)$ was obtained for the pairs MNCO3-731C-21 and California Blackeye-27 from different geographic origin, Brazil and USA, respectively, which may have contributed to the greater dissimilarity between them. Nevertheless, the lower values of $D^{2}$ shown by the genotypes TVx-5058-09C with MNC03-732C-21 (1.60) and the genotype Viana Blanca with BRS Potengi 13.62), also from different geographic origins, showing little effect of geographic origin on the dissimilarity between these pairs of genotypes. The lowest values of $D^{2}$ were observed for the pairs MNC01-614F-15 with Paulistinha (0.72) and MNC99-537F-14-2 with MNC01-649E-2 (0.95), meaning greater similarity among the considered traits (Table 4).

Moreover in relation to Table 4, it should be noted that the maximum values of $D^{2}$, regardless the genotypes, were obtained whit a combination of MNCO3-731C-21 and California Blackeye-27, indicating these as the most divergent among the evaluated germplasm group. Maximum values of $D^{2}$ of high magnitude were obtained between the genotype MNCO3$731 \mathrm{C}-21$ when combined with MNC05-832b-234-5, MNC01-649E-2, Paulistinha, Canapuzinho, BRSParaguassu and BRS-Milênio and between the genotype California Blackeye-27 with the genotype Viana-Blanca.

These genotypes are therefore the most indicated forthe hybrid combination in the initial stages of a breeding program, with the expectation that, due to genetic divergence, hybrid production with greater heterotic effect will be obtained, raising the chances of favorable gene combinations that allow the selection of superior genotypes. The large amplitude of $D^{2}$ and the high values estimated for most of the pairs of cultivars reveal the great genetic variability existing in this group of genotypes, which makes identification of parents, possible by the formation of a population with a broad genetic base, increasing the probability of obtaining superior genotypes in the segregating generations.

Considering Tocher's grouping, minimum values for $D^{2}$ were obtained between groups I and V (29.4135), group I and III (34.8662) and group I and II (36.9961); these low values mean that crossing the genotypes of these respective pairs of groups may not be greatly indicated for obtaining superior genotypes in the segregating generations, due to their proximity (Table 5). 
Table 4. Least and greatest Mahalanobis distances ( $\left.D^{2}\right)$ among 40 cowpea genotypes.

\begin{tabular}{|c|c|c|c|c|c|}
\hline \multirow{2}{*}{\multicolumn{2}{|c|}{ Genotypes }} & \multicolumn{4}{|c|}{$\mathrm{D}^{2}$ Distance between genotypes } \\
\hline & & \multicolumn{2}{|c|}{ Shortest } & \multicolumn{2}{|c|}{ Greatest } \\
\hline 1 & MNC99-537F-1 & 3.87 & 20 & 86.38 & 13 \\
\hline 2 & BRS Tumucumaque & 4.91 & 20 & 102.39 & 13 \\
\hline 3 & MNC99-541F-5 & 3.95 & 10 & 91.72 & 13 \\
\hline 4 & MNC99-541F-8 & 2.34 & 5 & 69.10 & 13 \\
\hline 5 & BRS Potengi & 1.05 & 7 & 57.54 & 19 \\
\hline 6 & BRS Novaera & 1.07 & 12 & 76.56 & 19 \\
\hline 7 & MNC00-553D-8-1-2-3 & 1.05 & 5 & 59.11 & 19 \\
\hline 8 & MNC99-557F-2 & 13.34 & 7 & 97.85 & 19 \\
\hline 9 & MNC01-627F-14-2 & 2.37 & 16 & 112.86 & 13 \\
\hline 10 & MNC01-627F-14-5 & 2.50 & 11 & 71.65 & 13 \\
\hline 11 & MNC03-720C-20 & 1.68 & 5 & 65.75 & 13 \\
\hline 12 & MNC03-720C-31 & 1.07 & 6 & 67.20 & 19 \\
\hline 13 & MNC03-731C-21 & 27.76 & 18 & 219.49 & 19 \\
\hline 14 & MNC03-732C-5 & 1.60 & 15 & 75.06 & 19 \\
\hline 15 & $T V x-5058-09 C$ & 1.60 & 14 & 85.94 & 19 \\
\hline 16 & MNC05-784b-38-2 & 2.37 & 9 & 104.02 & 13 \\
\hline 17 & MNC05-832b-234-5 & 3.18 & 9 & 133.78 & 13 \\
\hline 18 & Vaina Blanca & 13.62 & 5 & 108.26 & 19 \\
\hline 19 & californiablackeye-27 & 23.19 & 17 & 219.49 & 13 \\
\hline 20 & BRS Guariba & 3.87 & 1 & 97.93 & 13 \\
\hline 21 & MNC99-510F-16-1 & 2.28 & 23 & 72.13 & 13 \\
\hline 22 & MNC99-510F-16-3 & 2.56 & 5 & 59.38 & 19 \\
\hline 23 & MNC99-537F-14-2 & 0.95 & 25 & 66.27 & 13 \\
\hline 24 & MNC01-611F-11 & 1.75 & 32 & 111.57 & 13 \\
\hline 25 & MNC01-614F-15 & 0.95 & 23 & 66.72 & 13 \\
\hline 26 & MNC01-631F-11 & 5.78 & 29 & 111.48 & 13 \\
\hline 27 & MNC01-631F-15 & 7.53 & 32 & 74.78 & 13 \\
\hline 28 & MNC01-631F-20-5 & 8.33 & 30 & 98.88 & 13 \\
\hline 29 & MNC01-649E-2 & 0.72 & 35 & 131.98 & 13 \\
\hline 30 & Canapuzinho & 6.04 & 31 & 128.04 & 13 \\
\hline 31 & Canapuzinho-2 & 4.63 & 24 & 112.22 & 13 \\
\hline 32 & Inhuma & 1.75 & 24 & 97.75 & 13 \\
\hline 33 & Pingo-de-ouro-1-2 & 2.43 & 34 & 112.26 & 13 \\
\hline 34 & Pingo-de-ouro-2 & 2.43 & 33 & 113.64 & 13 \\
\hline 35 & paulistinha & 0.72 & 29 & 131.64 & 13 \\
\hline 36 & Patativa & 4.56 & 21 & 66.69 & 19 \\
\hline 37 & BRS Paraguassu & 7.20 & 24 & 128.15 & 13 \\
\hline 38 & BRS Milênio & 3.46 & 24 & 125.41 & 13 \\
\hline 39 & BR 17-Gurguéia & 3.57 & 40 & 98.24 & 13 \\
\hline 40 & BRS Marataoã & 2.47 & 23 & 88.9 & 13 \\
\hline
\end{tabular}

The greatest average distances were obtained between groups IV and $V$ (219.4953), groups II and VI (103.0585) and groups III and IV (102.3998), corresponding to the greatest divergences among groups and probably, indicating the best combinations for crosses. Identification of superior genotypes based on genetic divergence is an adequate strategy for a breeding program. However, the choice of genotypes must also be made considering their behaviors per se; that is, crosses are recommended between divergent genotypes, but which also show superior performance in relation to the main agronomic characteristics.

The use of the Tocher optimization method based on dissimilarity expressed by the Mahalanobis distances (D2), allowed the formation of six distinct groups, with $85 \%$ of the genotypes belonging to group I. Groups III, IV, $\mathrm{V}$ and $\mathrm{VI}$ were formed by individual genotypes (Table 6). 
Table 5. Mean distances within the groups in the main diagonal and among groups outside of the main diagonal corresponding to the six groups formed by 40 cowpea genotypes by the Tocher optimization method.

\begin{tabular}{ccccccc}
\hline Groups & I & II & III & IV & V & VI \\
\hline I & 19.3785 & 36.9961 & 34.8662 & 88.8202 & 29.4135 & 47.9283 \\
II & & 19.69 & 37.7893 & 38.8558 & 48.0672 & 103.0585 \\
III & & & - & 102.3998 & 76.2151 & 47.4862 \\
IV & & & & - & 98.8877 & 219.4953 \\
V & & & & & - & 68.9792 \\
VI & & & & & & - \\
\hline
\end{tabular}

Table 6. Clustering and sub-clustering of 40 cowpea genotypes by Tocher's optimization method

\begin{tabular}{|c|c|c|c|c|c|c|c|c|c|c|c|c|}
\hline Groups & & & & & Acces & & & & & & & \\
\hline \multirow{3}{*}{ I } & 14 & 15 & 7 & 5 & 12 & 11 & 22 & 25 & 4 & 10 & 23 & 29 \\
\hline & 35 & 38 & 24 & 26 & 32 & 31 & 39 & 40 & 33 & 30 & 9 & 17 \\
\hline & 16 & 3 & 21 & 36 & 1 & 20 & 6 & 34 & 37 & 27 & & \\
\hline II & 8 & 18 & & & & & & & & & & \\
\hline III & 2 & & & & & & & & & & & \\
\hline IV & 13 & & & & & & & & & & & \\
\hline V & 28 & & & & & & & & & & & \\
\hline VI & 19 & & & & & & & & & & & \\
\hline
\end{tabular}

Regarding the cut in the dendrogram, in approximately $50 \%$ of dissimilarity, the formation of three groups was observed (Figure 1). The least dissimilarity was between genotypes 29 and 35 (MNC01-649E-2 and Paulistinha). These results indicates that hybridizations between MNCO1649E-2 and Paulistinha may result in the generation of very similar progenies with a very narrow genetic base. On the other hand, depending on the strategy of the breeding program, this type of cross, considered as convergent, may facilitate the work of breeders in the selection of superior lines in less time because both cultivars have superior performance in important agronomic characteristics, such as productive potential.

The Cophenetic Correlation Coefficient (CCC) obtained was 0.892 and significant ( $p<$ $0.1)$ by the t test. Only cophenetic correlation values greater than 0.80 indicates a good fit between the original matrices of distance and the graph distances (Sokal and Rohlf, 1962), with cophenetic correlation being adequate, showing that the representativeness of the real distance between the genotypes by means of graphic representation of the dendrogram is trustworthy (Figure 1).

It may be observed that in both cluster analysis techniques, there was the formation of groups with prostrate growth habit genotypes (genotypes from 21 to 40) and upright growth habit genotypes (genotypes from 1 to 20). Passos et al. (2007), evaluating genetic divergence in cowpea, divided the genotypes by upright and prostrate growth habit; however, it may be suggested that the growth habit of the plant does not have an effect on the variables used for cluster analysis in this study.

The first three principal components (CP1, CP2 and CP3) explained $83 \%$ of the total variation. Thus, the study of genetic dissimilarity in the three-dimensional space was able to be performed (Figure 2A). With the evaluation of the groups formed by means of this clustering technique, the establishment of six groups may be observed, as the individualization of the genotypes MNC03-731C-21 and California Blackeye-27 (13 and 19).

The estimates of the eigenvalues corresponding to the first three canonical variables explained $82 \%$ of the total variation, with the study of genetic dissimilarity also having been performed in the three-dimensional space (Figure 2B). The formation of four groups can be observed, with agreement with the results obtained by UPGMA methods. Santos et al. (2011) also verified that the cluster methods by the average connection among groups and the canonical variables were previously in agreement among themselves. 


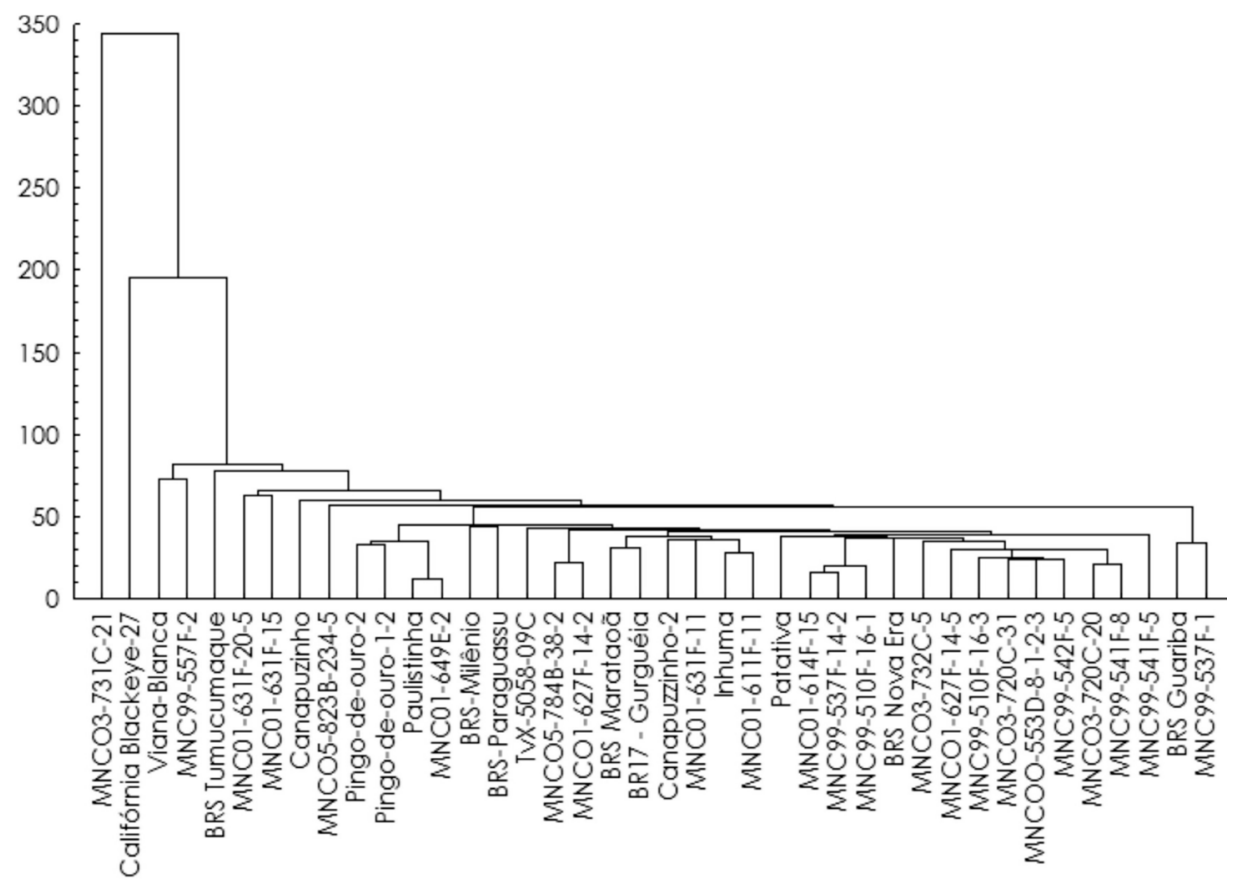

Figure 1. Dendrogram representing genetic dissimilarity among the 40 genotypes studied, obtained by the mean connection among groups (UPGMA), using the Mahalanobis generalized distance as a dissimilarity measure. Cophenetic correlation (0.892). (G1, G2, and G3 indicate groups 1, 2 and 3, respectively).
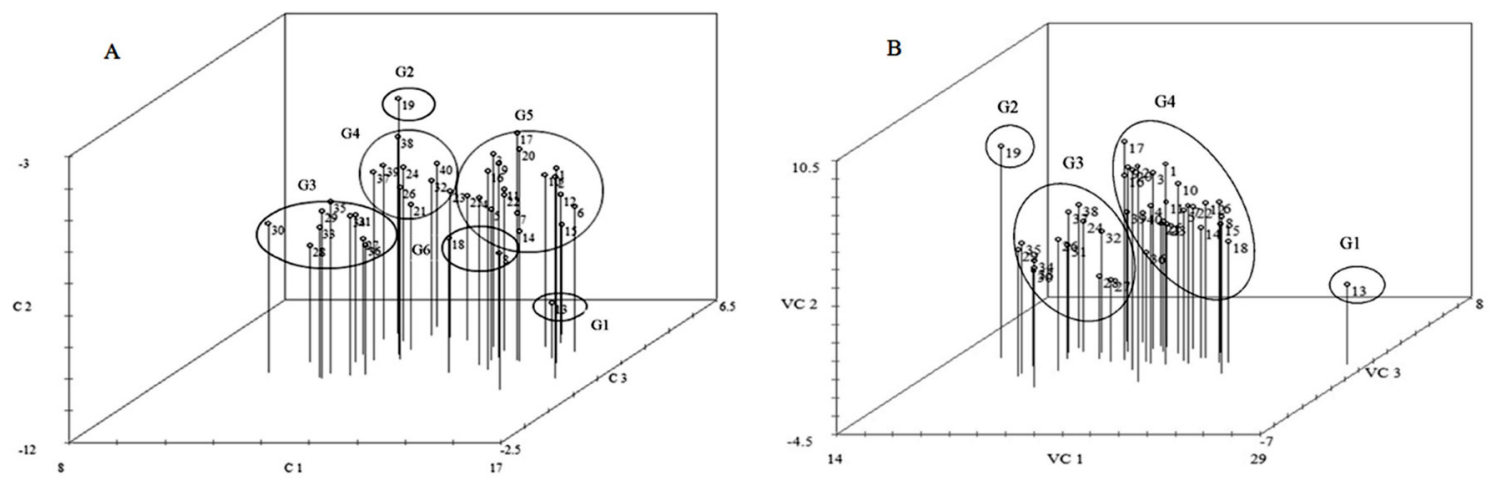

Figure 2. Graph dispersion obtained by means of the principal components evaluated as of seven agronomic traits in 40 cowpea genotypes. (G1, G2, G3, G4, G5 and G6 indicate groups 1, 2, 3, 4, 5 and 6, respectively) (A). Score dispersion of 40 cowpea genotypes in relation to three canonical variables (VC1, VC2 and VC3), based on evaluation of morphoagronomic characteristics (G1, G2, G3 and G4 indicate groups 1, 2, 3 and 4, respectively) (B).

Even though the cluster methods used are different, there was a certain similarity in the order of group formation, concludingthat the methods were efficient in clustering the genotypes MNC03-731C-21 and California Blackeye-27 ( 13 and 19, respectively) in individual groups.

The multivariate techniques applied were partially in agreement among themselves, following the same tendency in clustering the genotypes. Directed crosses between the genotypes belonging to group I with group IV and VI will be able to lead to the creation of segregating families with high productive potential and an increase in the probability of recovering superior genotypes. The variables of hundred grain weight, average pod length and number of seeds per pod are the main determinants in quantification of the genetic divergence among the cultivars. 


\section{References}

Bezerra Neto, F.V.B., Leal N.R., Gonçalves, L.S.A., Rêgo Filho, L.M., Amaral Júnior, A.T., 2010. Descritores quantitativos na estimativa da divergência genética entre genótipos de mamoneira utilizando análises multivariadas. Revista Ciência Agronômica 41: 294-299.

Bertini, C.H.C.M., Almeida, W.S., Silva, A.P.M., Silva, J.W.L., Teófilo, E.M., 2010. Análise multivariada e índice de seleção na identificação de genótipos superiores de feijão-caupi. Acta Scientiarum Agronomy 32: 613-619.

Cabral, P.D.S., Soares, T.C.B., Lima, A.B.P., Soares, Y.J.B., Silva, J.A., Nunes, J.A., 2011. Diversidade genética de acessos de feijão comum por caracteres agronômicos. Revista Ciência Agronômica 42: 898-905.

Cruz, C. D.; Regazzi, A. J.; Carneiro., 2006. Modelos biométricos aplicados ao melhoramento genético. 4. ed. Viçosa: UFV, 2006. 390 p.

Cruz, C.D. 2013. GENES - a software package for analysis in experimental statistics and quantitative genetics Acta Scientiarum Agronomy .35: 271276.

Dias, T.C., Silva, A.P.M., Bertini, C.H.C.M., 2009. Genetic divergence in cowpea genotypes with upright growth and early cycle Crop Breeding and Applied Biotechnology 9: 253-259.

Dutra Filho, J.A., Resende, L.V., Bastos, G.Q., Simões Neto, D.E. Machado, P.R., 2013. Utilização de marcadores moleculares RAPD e EST's SSR para estudo da variabilidade genética em cana-de-açúcar. Revista Ciência Agronômica 44: 141-149.

Elias, H.T., Vidigal, M.C.G., Gonela, A., Vogt G.A., 2007. Variabilidade genética em germoplasma tradicional de feijão-preto em Santa Catarina. Pesquisa Agropecuária Brasileira 42: 1443-1 449.

Ferreira, M.E., Moretzsohn, M.C., Buso, G.S.C., 2007. Fundamentos de caracterização molecular de germoplasma vegetal. In: NASS LL (ed.) Recursos Genéticos Vegetais. Embrapa Recursos Genéticos e Biotecnologia, Brasília, 377-420p.

Gonçalves, M.C., Fritsche-Neto, R., 2012, Tópicos especiais de biometria no melhoramento de plantas: com exemplos numéricos e de programação no SAS®. Editora Suprema, Visconde do Rio Branco, 282p.

Nagalakshmi, R.M., Usha Kumari, R., Boranayaka, M.B., 2010. Assessment of genetic diversity in cowpea (Vigna unguiculata). Electronic Journal of Plant Breeding 1: 453-461.

Oliveira, F.J., Anunciação Filho, C.J., Bastos, G.Q.,
Reis, O.V., 2003. Divergência genética entre cultivares de caupi. Pesquisa Agropecuária Brasileira 38: 605-611.

Passos, A.R., Silva, S.A., Cruz, P.J., Rocha, M.M., Cruz, E.M.O., Rocha, M.A.C., Bahia, H.F., Saldanha, R.B., 2007. Divergência genética em feijão-caupi. Bragantia 66: p.579-586.

Pinto, I.C.P., Sousa, A.M., Carvalho, D., 2004. Variabilidade genética por isoenzimas em populações de Copaifera langsdorffii Dest. em dois fragmentos de mata ciliar. Scientia Forestalis 65: 40-48.

Santos, E.F.N., Santoro, K. R., Ferreira, R.L.C., Santos, E.S., Santos, G.R.A., 2010. Formação de grupos produtivos em vacas leiteiras por meio de componentes principais. Revista Brasileira de Biometria 28: 15-22.

Santos, E.R., Barros, H.B., Ferraz, E.C., Cella, A.J.S., Capone, A., Santos, A.F., Fidelis, R.R., 2011. Divergência entre genótipos de soja, cultivados em várzea irrigada. Revista Ceres 58: 755-764.

Sokal, R.R., Rohlf, F.J., 1962. The comparison of dendrograms by objective methods. Taxonomy 11:33-40. 